\title{
CHANGES IN ATTITUDES TOWARDS RUSSIA AMONG THE LITHUANIAN-POLISH ELITE AT THE TURN OF THE SEVENTEENTH AND EIGHTEENTH CENTURIES
}

\author{
Gintautas Sliesoriūnas
}

ABSTRACT This article deals with the rise of the manifestation of servilism among the Polish-Lithuanian nobility in relation to Russia in the first quarter of the eighteenth century. Although the entire rule of Augustus II (1697-1733) is investigated in this study, the main attention is focused on the period after the 1719 Treaty of Vienna, when the King attempted to reduce his dependence on Russia, while the latter energetically began forming a clique of adherents among the Commonwealth's noblemen to compromise royal policy. In this activity Russia was most successful among the nobility of the Grand Duchy of Lithuania. This work analyzes Russian diplomats' methods, including bribery and intimidation.

This research is based on documents from the Archive of the Foreign Policy of the Russian Empire.

From megalomania to servilism - such was the evolution of the attitude taken by the elite of the Grand Duchy of Lithuania and the Polish Kingdom to Russia in the life of politicians of a single generation. That was the era of the rule of Augustus II in the PolishLithuanian Commonwealth (1697-1733) and of the reign of Peter I in Russia (1689-1725). The tendency towards servilism grew and overwhelmed the King's court and more and more engulfed the gentry. In Lithuania this process proceeded more rapidly than in Poland. The greater part of the Lithuanian gentry lost confidence in the capabilities of the Commonwealth to defend state interests in the European arena and also lost faith in the goodwill of the King himself as a representative of the Wettin dynasty ruling in Saxony. This was the aftermath of direct internal and external convulsions the civil war between the Sapiegas and their enemies 'the Republicans' (1697-1702), the Northern War (1700-1702), the internal war between Augustus II and the Swedish-sponsored Stanisław Leszczyński, the armed conflict between the Commonwealth gentry 
and the closest adherents of Augustus II and the Saxon army, known as the Confederation of Tarnogród (1715-1717). Under these circumstances Russia came to be regarded as the guarantor of the state's external security and internal stability.

In the period under consideration, four stages can be distinguished in the relations between the elite of the Commonwealth (including the King) and Russia. The first stage (1697-1702) was characterized by an alliance of equal partners, of almost equal partners, since the Commonwealth was mostly in the role of the supplicant. In the second stage (1702-1706) the Commonwealth was a subsidized ally of Russia. The third stage covered the period between 1706 and 1719, when the Commonwealth became dependent on Russia as its junior partner. It was at this time - after Augustus II's abdication - that a part of the Commonwealth and of army, continuing the struggle against Sweden and refusing to acknowledge Leszczyński as their lawful ruler, began treating the Russian tsar not only as a source of material support in the campaign against the Swedes, but also as their supreme authority and arbiter. Lastly, the fourth stage lasted from the 1719 Treaty of Vienna to the end of Augustus II's reign. In a fictional account this stage could be referred to as the years when the 'Russian fifth column' became consolidated. In this period, having pushed his state into close political and military alliance with Russia, Augustus II attempted to change course and reduce the actual dependence of the Commonwealth on Russia. Thus the King became Russia's chief enemy, and Tsar Peter tried to organize a pro-Russian grouping among the nobility and gentry and to weaken the King and his followers within the Commonwealth and in future to destroy the personal union between the Commonwealth and Saxony. In this activity the majority of the Lithuanian noblemen became Russia's most reliable and active supporters. This study will be focused on the events of this last period, which so far has received least attention from researchers.

Returning to the manifestations of megalomania and servilism, it could be maintained that megalomania was typical of the attitude of a great part of the Commonwealth nobility and of Saxon ministers at the King's court in the first stage (1697-1702), and subsequently it was on the wane and showed itself only occasionally in caricatured forms.

Regrettably, in Lithuanian historical scholarship the year 1719 practically does not feature among turning points in relations with 
Russia. In that year Augustus II's delegates, representing him as a Saxon duke in Vienna, put their signatures to the treaty, by which the King joined a wide alliance of the European countries, led by Great Britain (its king was also Elector of Hanover). In addition, the alliance comprised the Holy Roman emperor, Prussia, some minor German states, Denmark and, formally, France. ${ }^{1}$ The coalition was directed against Russia, which was forced to agree to the terms of the ultimatum and withdrew its forces from Northern Germany (the Duchy of Mecklenburg) and the Polish-Lithuanian Commonwealth. The coalition also threatened to declare war if Russia did not stop waging war against Sweden. Besides, the Empire was facing the impending conflict with Turkey. Thus, Russia could lose all its gains from the twenty-year-long Northern war, which had been almost won.

The importance of preserving the Commonwealth within the Russian sphere of influence is evident from the contemporary diplomatic correspondence. For example, the Russian envoy to the Netherlands, Prince Boris Ivanovich Kurakin, wrote to his colleague in Warsaw that nothing could serve the interests of the tsar better than the preservation of the Commonwealth's alliance with Russia because all unfriendly states would not be able to do any serious harm to Russia before previously drawing the Commonwealth to their side. ${ }^{2}$ Similar messages were sent more than once by the Russian envoy to his superiors in St Petersburg. ${ }^{3}$

The period between 1719 and 1733 is the last (prior to the Four Years Sejm) when the King of the Commonwealth conducted an independent policy, an aim of which was to curb Russian influence on the state. In return Russia reacted by agreeing to withdraw its troops from Northern Germany and the Commonwealth, speeded up the peace talks with Sweden and ended them in 1721. On the other

${ }^{1}$ L.R. Lewitter, 'Poland, Russia and the Treaty of Vienna of 5 January 1719', Historical Journal, 13, (1970), pp. 3-30; U. Kosińska, 'Rosyjskie plany wywołania antykrólewskiej konfederacji i detronizacji Augusta II w 1719 r.’, Kwartalnik Historyczny, 106, (1999), 3, pp. 53-75; idem, Sejm 1719-1720 a sprawa ratyfikacji traktatu wiedeńskiego (Warsaw, 2003).

${ }^{2}$ Kurakin to Grigorii Dolgorukii, the Hague, copy of the letter 15 (26) Dec. 1719. Attachment to Dolgorukii's Warsaw report no. 31 of 16 (27) Jan. 1720 to Peter I, Arkhiv vneshnei politiki Rossiiskoi imperii (henceforth AVPRI), f. 79 (Snosheniia Rossii s Polshei), op. 1, 1720, d. 7, fo. 53.

${ }^{3}$ G. Dolgorukii to Peter I, report no. 37, Warsaw, 22 Oct. (2 Nov.) 1720, ibid. d. 7a, fos. 99--102; G. Dolgorukii to Peter I, report no. 38, Warsaw, 29 Oct. (9 Nov.) 1720 , ibid. fos. 125-128. 
hand, in the Commonwealth it started organizing a grouping of adherents, directed against the King and Saxony. In other words, it began 'protecting the Poles against German tyranny'. For example, it insisted that 'as envoys only Poles' would be sent to St Petersburg. ${ }^{4}$ Internationally Russia started the formation of a system of guarantees for the Commonwealth - concluded treaties with other European states containing pledges of ensuring the territorial integrity and 'republican order', i.e. the prevention of any radical reform of the regime. That meant the opposition to any changes of the existing order of royal election, liberum veto, and other established privileges in respect to both the king and the high officials. ${ }^{5}$ The Commonwealth had to become a barrier safeguarding Russia from any possible danger from the West and enabling it to act freely on its own initiative.

The nobility of the Grand Duchy of Lithuania became the mainstay of Russian support in the Commonwealth, stifling any political initiatives by their own king in an organized way and fighting against Saxon influence. ${ }^{6}$ Former enemies paradoxically formed this pro-Russian anti-royal union. The first group consisted of those noblemen who in the Northern War fought against Sweden and its protégé Leszczyński, that is, the former Augustus II's adherents, who after 1719 had to choose between loyalty to their king or loyalty to Russia. Their absolute majority preferred the second alternative. The other grouping comprised the Sapiegas, who were on the side of Sweden and Leszczyński during the Northern War. After Augustus II's quarrel with Russia these noblemen enthusiastically continued the struggle against Augustus II by political means but already with Russian political and financial support. Everybody expected that the personal union between the Commonwealth and Saxony would be dissolved sooner or later. 'Sooner' meant before

${ }^{4}$ Po nashemu ukazu govoreno zdes' upomianutomu pol'skomu poslu...o prisylke ko dvoru nashemu ot korolia i Rechi Pospolitoi na rezidenciiu ministra pol'skogo prirodnogo,...i vam...staratca, chtob kto is pol'skoi natsii $i$ dobrozhelatelnoi Rechi Pospolitoi, a ne is korolevskikh kreatur - Peter I (Russian College of Foreign Affairs) to G. Dolgorukii, instruction of 24 July (4 Aug.) 1720, ibid, d. 5, fo. 65.

5 J. Staszewski, Jak Polske przemienić w kraj kwitnqcy... Szkice i studia z czasów saskich. Rozprawy i Materialy Ośrodka Naukowych im. Wojciecha Kętrzyńskiego w Olsztynie, nr. 168, (Olsztyn), 1997, p. 119.

${ }^{6}$ J. Kurek, U schytku panowania Augusta II Mocnego. Z dziejów wewnętrznych Rzeczpospolitej (1729-1733), [Prace Naukowe Uniwersytetu Ślaskiego w Katowicach, no. 2112] (Katowice, 2003), pp. 93, 104, 141. 
Augustus' death, that is, after his dethronement. Some cherished naive hopes that Russia would resign itself to the re-enthronement of Leszczyński, who lived in emigration.

Strengthening its influence, Russia applied the established carrot and stick technique. The more the Commonwealth depended on Russia, the smaller was the carrot and the heavier, the stick. Since 1720 Russia had endeavoured to control the sessions of the Sejm (in 1720 it initiated the disruption of two sejms ${ }^{7}$ ). The main aim was to prevent the ratification of the Treaty of Vienna signed in 1719, as that would mean the formation of an anti-Russian coalition. After the first disrupted sejm the Russian ambassador was instructed in what way he had to strengthen the grouping of Russian adherents among Commonwealth noblemen. He had to thank them for their service and to assure them that Russia would remain a loyal and trusted ally of the Commonwealth without any hostile intentions. The ambassador had to reassure the noblemen that what they did at Russia's request they did for the benefit of the two states, that is, both Russia and the Commonwealth. The noblemen also had to be sure that Russia would never turn away from them once they had done some service for the empire. And finally, those who had been in service had to be remunerated. ${ }^{8}$ The contemporary rewards were furs, commodities from China, and money. ${ }^{9}$ Before each new sejm the ambassador had to widen the circle of Russian supporters among the noblemen, to promise them Russian favour and benevolence, and he could give the needy ones

7 ... a s tekh 10,000 chervonnykh eshche pered seimom po ukazu vashego velichestva 2,000 strazhniku, kotoroi nyne voevodoiu belskim, dano. I tem vse korolevskie protivnye dela na seime oproverg - G. Dolgorukii to Peter I, Warsaw, report no. 14 of 9 (20) Apr. 1720, AVPRI, f. 79, op. 1, 1720, d. 7, fos. 221v-223v. Concerning the second sejm: Ia zdes' vsemi merami neusypno truzhdaius', chtob nyneshnii seim nenachinalsia $i$ bez deistva na polozhennoi termin rozsholsia G. Dolgorukii to Peter I, Warsaw, report no. 36 of 10 (26) Oct. 1720, ibid., d. 7a, fos. 85-87; ...ia $v$ svoiu storonu vsemi merami truzhdaius' $i$ nedopushchaiu poslov ne tokmo do nachinania seimu [no] i do obraniia marshalka- G. Dolgorukii to Peter I, Warsaw, report no. 37 of 22 Oct. (2 Nov). 1720, ibid., fos. 99-102.

${ }^{8}$ Peter I (Russian College of Foreign Affairs, St Petersburg) to the Russian envoy in Warsaw G. Dolgorukii, instruction no. 8 of 18 (29) March 1720, ibid, d. 5, fos. 12-14.

9 ...i ne izvolite, gosudar', chto $v$ zapas prislat', takozhe $i$ dlia podarkov iz narochitykh kitaiskikh veshchei, chto mozhet vo vremeni zasluzhit' nemaloi tseny - G. Dolgorukii to Peter I, report no. 14 from Warsaw, 9 (20) Apr. 1720, ibid., d. 7 , fos. $221 \mathrm{v}-223 \mathrm{v}$. 
'a financial gift' in advance. ${ }^{10}$ When in 1720 it was rumoured that Peter I might become reconciled with Augustus II, the Russian ambassador was instructed to inform loyal noblemen in the Commonwealth that the tsar would be reconciled with the King only on condition that such a step would be approved by his Russian friends among the Polish noblemen. ${ }^{11}$ An analysis of all these instructions shows that in recruiting the noblemen of the Commonwealth, the Russian diplomatic service had to appeal to both feelings and reason and take into account views as well as interests. To appeal to the instinct of self-preservation, in other words, to allay the fears of the nobility, Russia assured that it would not let its allies down and in case of danger would defend them. The feeling of importance (or, to be more sarcastic, of vanity) of the nobility was also taken into account. Russia conveyed the impression that it valued the opinion of the nobility and by 'thanking' it created the illusion of attaching significance to the noblemen's advice allegedly influencing Peter I's policy. The appeal to conscience upheld the view that the noblemen, helping Russia, were acting in the interests of their own state and preserving the rights and freedoms of its citizens. After all, the most real danger was the King, the Saxons and their adherents in the Commonwealth. Those noblemen whose decisions were conditioned by rational arguments had to be convinced by statements that helping Russia they enabled the Commonwealth to avoid new calamities - taking part in a new war or becoming a theatre of a new war. The latter argument was particularly convincing for the Commonwealth's population that had suffered badly in the Northern War. Therefore Russia systematically resorted to

10 ...takozhe staratsia vam iskat' nyne skloniat' $k$ nashei strane i prochikh magnatov polskikh,...tekh nadlezhit vam takozhe nasheiu sklonnoiu priiazniu $i$ vpred' nagrazhdeniem obnadezhivat', ili i nyne za ranee komu iz onykh ezheli za potrebno byt' usmotrite uchinit kakuiu dachiu is upomianutoi zhe nashei kazny, chtob ikh tem viashche obiazat' $v$ ynteres nash $i v$ pred' ugotovit' ko vspomozheniiu nam na budushchem seime - Peter I (Russian College of Foreign Affairs, St Petersburg) to the Russian envoy in Warsaw G. Dolgorukii, instruction no. 8 of 18 (29) March 1720, ibid, d. 5, fos. 12-14.

11 ...imeete vy takozhe u dobrozhelatel'nykh $k$ nam magnatov uvedomitsia, budet li onym sie primirenie priiatno tokmo po ikh zhelaniiu postupaem $i$ dlia togo takozhde $v$ tom nichego uchinit' ne budem, kak s obshchago snimi soglasiia i soveta - Peter I (Russian College of Foreign Affairs, St Petersburg) to the Russian envoy in Warsaw G. Dolgorukii, instruction no. 45 of 12 (23) Dec. 1720, ibid, d. 5, fos. 103-107. 
this topic. ${ }^{12}$ Lastly, each good turn deserved another, and the services to Russia were always paid lavishly.

It must be stressed that at that time the funds of the Russian embassy were rather meagre and much smaller than those of the Prussian, Austrian or French embassies, especially at the end of the seventeenth century. The then Moscow envoy to the Commonwealth, Aleksei Nikitin, being in hopeless financial trouble begged his sovereign, according to all the rules of contemporary Muscovite rhetoric, 'not to let him and his children die of hunger in Warsaw'. That might have been some exaggeration, but his complaint that he could hardly afford a carriage and did not walk on foot in Warsaw only because he feared to transgress the tsar's regulations and did not want to be the laughing-stock of other diplomats seemed quite reasonable. ${ }^{13}$ Financial problems did not disappear later on as well, when Grigorii Dolgorukii became Russian envoy. Nevertheless, no matter how difficult its financial situation was, Russia always kept its pecuniary promises that it had given to the Commonwealth's noblemen. For that purpose Russia even borrowed money from other ambassadors (3,000 roubles from the Prussian ambassador during the sejm of $1722^{14}$ ), did not pay salaries to its officials (in

12 ...vy imeete...senatorem $i$ ministram $i$ drugim znatneishim chinam Rechi Pospolitoi pol'skoi pristoinym obrazom vnushat' $i$ tolkovat'...osoblivo o tom, kak khotiat voiska drugikh potentsei $v$ Pol'she sluchit' $i$ tamo teatrum voiny perenest' i uchinit - Peter I (Russian College of Foreign Affairs, St Petersburg) to the Russian envoy in Warsaw G. Dolgorukii, instruction no. 41 of 17 (28) Oct. 1720, ibid, fos. 8989v. Also cf. A chto...do namereniia Angliiskogo i Shvedskogo daby budushchuiu kompaniiu voiski v Pol'shu vvodit' prinadlezhit, to imete vy magnatov nakrepko uverit', chto ezhelib do togo doshlo, my Rech' Pospolituiu bez pomoshchi neostavim i nepriiatelei do rasshireniia $v$ Pol'she nedopustim, tokmo b onye tverdo pri nas derzhalis' $i$ sebia chrez intrigi nepriiatel'skie provesti nedopustili Peter I (Russian College of Foreign Affairs, St Petersburg) to the Russian envoy in Warsaw G. Dolgorukii, instruction no. 45 of 12 (23) Dec. 1720, ibid, d. 5, fos. 103-107.

13 ...umiloserditesia gosudari nad moeiu nishchetoiu... Ne radi menia ubogovo, no radi ego gosudarskoi chesti, chtob mne bednomu zdes' pered postoronnimi poslanniki $i$ rezidenty, i roznymi narody ot nedoststku svoego v poruganii $i$ v posmekhe ne byt', i golodnoiu i kholodnoiu smert'u ne umeret'. ...A peshi brodit['] bez ukazu velikogo gosudaria ne smeiu. ... Odolzhal i oskudel bez ostatku - Nikitin's report of 17 (28) February 1698 from Warsaw to the Great Legation in Amsterdam, Russian State Archive of Early Acts (henceforth RGADA), f. 79, op. 1, 1698, d. 3, fos. 26-26v.

14 Peter I (Russian College of Foreign Affairs, St Petersburg) to the Russian envoy in Warsaw Sergei Dolgorukii, instruction no. 19 of 6 (17) Sept. 1722, ibid, 1722, d. 5, fos. 35-43v: the envoy was allowed to borrow up to 3,000 roubles for bribes and other expenses related to the sejm. Cf. Peter I (Russian College of Foreign Affairs, St Petersburg) to the Russian envoy in Warsaw S. Dolgorukii, instruction no. 3 of 1 (12) Febr. 1723, ibid, 1723, d. 6, fos. 5-6v: Prussia asked S. Dolgorukii to repay 2,000 'red złoty' (thalers), borrowed on the occasion of the 1722 sejm. 
1720 the wages of the members of the embassy were frozen for eleven months ${ }^{15}$ ), and did not pay the rent for the ambassador's residence (Beloti's house). ${ }^{16}$ Since ambassadorial posts were occupied by the members of the wealthy Dolgorukii family for almost 30 years, they could use their own resources for political purposes, thus granting credits to the Russian state. ${ }^{17}$ It is obvious how important it was for Russia to make a good name for itself as a reliable party in such a sensitive sphere as making payoffs.

Thus, a Lithuanian or Polish nobleman acting for Russia and thwarting the King's plans and the affairs of state by disrupting the work of the sejms and dietines, obstructing the activity of the Tribunal and other courts, had to fancy himself, in modern terminology, a defender of Commonwealth's national interests and could justly be glad that Russia respected, rewarded and protected him for such noble work.

In the second and third decades of the eighteenth century the Polish and Lithuanian nobility did not foresee any threat to the existence of the state. They only feared that the country could be involved in some sort of military adventure, as in 1700, or become a victim of some agreement between King Augustus II and neighbouring rulers, thus endangering the territorial integrity of the state. Almost before each sejm Russia (as well as Prussia) took care that such apprehensions would grow. On such occasions rumours usually specially fabricated in Berlin or St Petersburg were spread. In $1772^{18}$ and 1723 Prussia trumped up reports that Augustus II was going to

15 ...no i kanceliaristy kotorye pri mne bez zhalovaniia odinadtsat' mesiatsev $v$ velikoi nuzhde z golodom obretaiutsia - G. Dolgorukii to Peter I, report no. 37, Warsaw, 22 Oct. (2 Nov.) 1720, ibid., 1720, d. 7a, fos. 99-102.

${ }^{16}$...khoziain togo domu, na kotorom stoial otets tvoi $i$ nynche ty stoish, Belotii kak na ottsa tvoego, tak $i$ na tebia mnogiia...zhaloby prinosil $i$ nynche prinosit ...o nasil'nom vashem stoianii $v$ domu ego $v$ Varshave chrez odinadtsat' let - Peter I (Russian College of Foreign Affairs, St Petersburg) to the Russian envoy in Warsaw S. Dolgorukii, instruction no. 17 of 20 Sept. (1 Oct.) 1723, ibid., 1723, d. 6, fos. 45-45v.

17 ...chto $i$ ko mne prislano iz domu moego dlia zdeshniago moego propitaniia zaimuia uderzhivaiu vashego velichestva vysoko iv sego gosudarstva interes nezhaleia upotrebliaiu - G. Dolgorukii to Peter I, report no. 37, Warsaw, 22 Oct. (2 Nov.) 1720, ibid. 1720, d. 7a, fos. 99-102.

18 ...po uchinennomu soobshcheniiu korolevskogo velichestva Prusskogo ministra barona Mardefelda o namerenii korolia Polskogo, daby pri nyneshnem v Varshave seime synu svoemu kurprintsu saksonskomu suktsesiiu na korolevstvo polskoe dostavit - 16 (27) Sept. 1772 protocol of the Secret Assembly of the Russian College of Foreign Affairs (with Aleksandr Menshikov present), ibid., 1722, d. 5, fo. 44. 
proclaim his son Frederick Augustus as his heir to the throne of Poland-Lithuania in the sejm. ${ }^{19}$ Although this practice - to hold an election vivente rege - was strictly forbidden in the Commonwealth, there had been such a precedent: Sigismund Augustus was elected to the throne on the wishes of his father Sigismund the Old. In 1722 even Russia swallowed a story concocted by Prussia and started actively mobilizing its adherents among the Lithuanian nobility, resorting to intimidation to use its forces. ${ }^{20}$ That was also an opportunity to satisfy various requests of the Lithuanian nobility, which previously Russia shunned - the field hetman of Lithuania Stanislovas Denhofas (Denhoff) was granted a trade privilege to buy timber in Russia and to export it customs free through the city of Riga, ${ }^{21}$ Letters of recommendation were issued to those noblemen who sought to marry the richest brides in the Commonwealth, among others to Denhofas, ${ }^{22}$ while the starosta of Bobruisk Jonas Kazimieras Sapiega (Sapieha) who also wanted to marry the same bride was promised the support of the Russian ambassador. ${ }^{23}$ Some minor requests were satisfied as well. Thus, the Prussian provocation played into the hands of a number of Lithuanian noblemen. A similar provocation, the so-called 'conspiracy of the Jews Lehmann and Meier' was recorded in 1721, before the 1722 sejm. Allegedly with Augustus II's knowledge, they offered Prussia, Austria and Russia the partition of the lands of the Commonwealth in exchange for the

19 ...pruskoi chrezvychainyi poslannik baron Mardefelt $v$ ymevshei $s$ ministrami nashimi konferentsyi ob'iasnil, chto korol' ego poluchil vedomost', chto korol' polskoi o suktsessii v Polshe naipache prezhniago staratetsia, $i$ chto ...korol' polskoi nameren radi polucheniia svoego namereniia ekstraordinarnoi seim v Polshe naznachit - Peter I (Russian College of Foreign Affairs, St Petersburg) to S. Dolgorukii, instruction no. 9 of 20 (31) May. 1723, ibid., 1723, d. 6, fos. 22-22v.

20 ...ezheli...ob opredelenii suktsessii cynu ego na seime predlozheno budet, dlia otvrashcheniia ot togo chinov Rechi Pospolitoi iz ministrov i poslov, kotorym on [S. Dolgorukii] za blago pazsudit...obiavil, chto i voiska ego Imperatorskogo Velichestva pri granitsakh polskikh gotovy na oboronu tem, kotorye ot korolia k opredeleniu onoi suktsesii nasilno prinuzhdaemy budut - 16 (27) Sept. 1772 protocol of the Secret Assembly of the Russian College of Foreign Affairs (with Aleksandr Menshikov present), ibid., 1722, d. 5, fo. 47.

${ }^{21}$ Peter I (Russian College of Foreign Affairs, St Petersburg) to S. Dolgorukii, instruction no. 29 of 18 (29) Sept. 1722, ibid., fos. 50-55v; Peter I (Russian College of Foreign Affairs, St Petersburg) to S. Dolgorukii, instruction no. 25 of 29 Nov. (10 Dec.) 1722, ibid., fos. 69-71.

${ }^{22}$ Ibid.

${ }^{23}$ Peter I (Russian College of Foreign Affairs, St Petersburg) to S. Dolgorukii, instruction no. 8 of 17 (28) May 1723, ibid., d. 6, fos. 19-21v. 
entrenchment of the hereditary monarchy in Poland. ${ }^{24}$ Behrend Lehmann was Augustus II's banker. ${ }^{25}$ Until as late as the middle of the twentieth century the historians did not doubt that the real instigator of the partition of the Commonwealth's lands was Augustus II himself. ${ }^{26}$ Subsequently this issue was increasingly treated as a Prussian provocation. ${ }^{27}$ Berlin immediately informed St Petersburg

24 ...o soobshchennykh nam vedomostiakh ot dvora pruskogo o predlozheniiakh chinennykh sego godu pri pruskom dvore so storony ego korolia polskogo sperva chrez prislanogo ot ego dvora Summa, a potom ot zhidov faktorov ego korolevskikh Lemana i Meiera o partazhe ili razdelenii Polshi - Peter I (Russian College of Foreign Affairs, St Petersburg) to S. Dolgorukii, instruction no. 8 of 10 (21) May 1721, ibid., d. 10, fos. 18-22.

${ }^{25}$ H. Schnee, Die Hoffinanz und der moderne Staat. Geschichte und System der Hoffaktoren an deutschen Fürstenhöfen im Zeitalter des Absolutismus, Bd. II: Die Institution des Hoffaktorentums in Hannover und Braunschweig, Sachsen und Anhalt, Mecklenburg, Hessen-Kassel und Hanau (Berlin, 1954), pp. 169-174, 181, 184-186.

26 Augustus II's responsibility was emphatically accentuated in Prussian historiography: J.G. Droysen, Geschichte der Preussischen Politik, T. iv, Bd. 2 (Leipzig, 1869), p. 317. A similar viewpoint is characteristic of Russian historical scholarship: S.M. Solov'ev, Istoriia Rossii s drevneishikh vremen. Nachalo 20-kh godov XVIII veka - 1725, kn. ix (t. 17-18) (Kharkov, 2003), pp. 404-405, 563. Polish historiography of the nineteenth and early twentieth century was disposed unfavourably towards Augustus II and did not question the reality of his schemes directed against the territorial integrity of the Commonwealth: W. Konopczyński, Polska a Szwecja od pokoju oliwskiego do upadku Rzeczpospolitej (16601795) (Warsaw, 1924), p. 95; idem, Najnowsze dzieje Polski, vol. 2 (Warsaw, 1936), p. 151; K. Morawski, Źródło rozbioru Polski (Poznań, 1935), pp. 142-143.

${ }^{27}$ Already Józef Felman's works displayed a certain uncertainty concerning Augustus II's initiatives in the preparation of the proposals of Lehmann and Meier and a belief that the Saxon field marshal J.H. Fleming was guiltless: J. Feldman, 'Flemming Jakub Henryk (1667-1728)', Polski stownik biograficzny, t. VII, z. 1, (Cracow, 1948), pp. 32-35. The German historian Ernest Hessinger, a researcher of Prussian politics, concluded that all the known plans of the partition of PolandLithuania, attributed to Augustus II, actually had been drawn in Berlin: E. Hassinger, Brandenburg-Preussen, Rußland und Schweden 1700-1713 (Munich, 1953), pp. 224-234. Currently this thesis is defended most vigorously by the Polish historian Jacek Staszewski: Staszewski, August II Mocny (Wroclaw, 1998), p. 7; idem, 'Jak Polskę przemienić, pp. 117-133. His works, however, present a more detailed study of a similar incident which took place in 1733 but not in 1721 . A recent paper by Grzegorz Chomicki dealing with the viewpoint of British diplomats on 'Lehmann's affair' of 1721 shows that irrespectively of its authorship (the British strongly suspected Augustus II) this affair seriously compromised the ruler of the Commonwealth and Saxony: G. Chomicki, 'Opinia dyplomatów brytyjskich o tzw. Aferze Lehmanna', Między Zachodem a Wschodem. Studia ku czci professora Jacka Staszewskiego, t. 2, ed. J. Dumanowski, et al. (Toruń, 2003), pp. 109-117. 
about this 'Jewish proposal'. Accordingly, Russia lodged an emotional protest, in which it manifested itself as a defender of the Commonwealth's territorial integrity. The protest was handed in to Augustus II as the Elector of Saxony. Simultaneously it was threatened that an analogous protest would be sent to the ruler as the King of Poland, if he continued his anti-Russian policy. ${ }^{28}$ That meant that this issue would be an object of open debate in the sejm. It was no easy task for Augustus II to prove his innocence to the gentry and nobility not really sympathizing with him that it was not he who proposed the partition of the lands in exchange for the support of the coup d'état. The Russian envoy in Warsaw was instructed to inform the nobility of the Commonwealth about the alleged initiative of the King to partition the state as soon as he resolved to take any anti-Russian action in the sejm. ${ }^{29}$ In 1720 Russia disseminated among the Polish and Lithuanian nobility the information that Augustus II had made an agreement with Great Britain, Prussia and Sweden to go to war against Russia. At that time the Royal Navy was in the Baltic Sea. Prussia was to gain Warmia ruled by Poland in exchange for a corps of 30,000 men, Sweden was to receive the Duchy of Courland and the palatinate of Livonia from the Commonwealth, and Augustus II was to become a hereditary monarch. ${ }^{30}$ When the Russian envoy in Warsaw asked his superiors in St Petersburg about how he should deal with the Prussian envoy in Warsaw after the conclusion of such an abominable anti-Russian pact, ${ }^{31}$ he was told most kindly and graciously, because Russia did not expect any unpleasantness from Prussia. ${ }^{32}$ Meanwhile Lithuanian and Polish noblemen were in a perpetual state of shock because they were warned constantly about impending catastrophes: the royal plots or

${ }^{28}$ Peter I (Russian College of Foreign Affairs, St Petersburg) to S. Dolgorukii, instruction no. 8 of 10 (21) Nov. 1721, AVPRI, f. 79, 1721, d. 10, fos. 20v-21.

${ }^{29}$ Ezheli s storony korolia polskogo interesam nashim kakie iavnye protivnosti budut, to...magnatom polskim o tom silnoe predstavlenie uchinit' $i$ obiavit'...takozhde o zhidovskom dele - Peter I (Russian College of Foreign Affairs, St Petersburg) to S. Dolgorukii, instruction no. 19 of 6 (17) Sept. 1722, ibid., 1722 , d. 5, fos. 35-43a.

30 'Authentic news received from Sweden', Peter I (Russian College of Foreign Affairs, St Petersburg) to G. Dolgorukii, appendix to the instruction no. 41 of 17 (28) Oct. 1720, ibid., 1720, d. 5, fos. 90-91.

${ }^{31}$ G. Dolgorukii to Peter I, report no. 40 of 19 (30) Nov. 1720, Warsaw, ibid., d. $7 \mathrm{a}$, fo. 156 .

${ }^{32}$ Peter I (Russian College of Foreign Affairs, St Petersburg) to G. Dolgorukii, instruction no. 45 of 12 (23) Dec. 1722, ibid., 1722, d. 5, fo. 104v. 
an impending new war on Lithuanian territory - Russia often hinted about a preventive deployment of its troops in order to repel the invader outside the boundaries of its territory. ${ }^{33}$ The escalation of a strong aversion to the King among the Lithuanian nobility produced its result: in 1729 the most influential magnates decided to disrupt all sejms until Augustus II's died. This decision was coordinated with Russia, and France was informed about it, too. The disruption had to precede the election of the sejm marshal, the chairman of the sejm. ${ }^{34}$ That was due to the peculiarities of the Commonwealth's political system; for example, hetmans could be appointed by the king only in the sejm after the election of a marshal. The most obvious result of the obstructionist activities of the Lithuanian nobility was the fact that after the king's demise the state did not have a single hetman (of four), that is, it lacked military leadership, provided by the law.

It was generally accepted in contemporary Europe that after Augustus II's death the election of a new king would be decided by Russian opinion. ${ }^{35}$ This situation was perceived by the majority of Lithuanian and a number of Polish nobles (but not the gentry). Meanwhile Russia did not hide its intentions to try and have 'a king friendly to Russia', ani Sas, ani Las, no Saxon or Stanisław Leszczyński, as it was popularly put. Therefore after 1719 each nobleman of any renown could hope to be rewarded by nothing less than a crown if he earned Russia's favour. After Augustus II's death in 1733, the British envoy to the Commonwealth counted twelve candidates for the post. ${ }^{36}$ During the lifetime of the King, the real candidates were Petras Sapiega, husband of Zofija Skowrońska, niece of Catherine I, Povilas Sanguška (Sanguszko), palace marshal of Lithuania, and the aforementioned Field Hetman Denhofas of

33 ...ia onym obiavliaiu, chto nyne voisk vashego velichestva obretaetsia pri granitse reguliarnykh okolo sta tysiach $i$ ezheli kakie aukhiliarnye voiska voidut $v$ Polshu, to vashe velichestvo uprezhdaia onykh izvolite svoi protiv onykh ne sprashivaia o doroge voitit', takozh i drugikh nereguliarnykh raznykh narodov vvesti izvolite, kotorye za proviant i furazh platit' ne budut $i$ uchiniat $v$ Polshe teatrum voiny, i budut v Polshe postupat' po nepriiatel'ski-G. Dolgorukii to Peter I, report of 15 (26) Oct. 1720, Warsaw, ibid., d. 7a, fos. 85-87.

${ }^{34}$ E. Rostworowski, O polska koronę. Polityka Francji w latach 1725-1733 (Wrocław-Cracow, 1958), p. 175; Kurek, U schytku panowania ..., pp. 112, 175.

${ }^{35}$ Rostworowski, O polska korone, pp. 38, 61.

36 'Rok 1733 w Polsce od śmierci Augusta II do elekcyi Augusta III, podług raportów dyplomatycznych ajentów angielskich', Przegląd Poznański, 32, (1861), p. 21. 
Lithuania. Thus, the political scenario, which was implemented subsequently by crowning Stanisław August Poniatowski, was constructed for the first time in the third decade of the eighteenth century. After Augustus II's death, Russia was not strong enough to play it out on its own.

Russian influence had permeated the entire political elite of Lithuania. A range of available choices of services was wide. For example, the starosta general of Žemaitija Kazimieras Zaranka (Zaranek), distinguished in the battles against the Sapiegas and the Swedes, a Lithuanian official most loyal to Russia, sent all kinds of information and reports to St Petersburg after 1719. However, the Russian ambassador in Warsaw admonished his superiors not to believe Zaranka's information since he always lied and vilified his rivals and other ill-willers. And in no way could he be paid any money for such reports. ${ }^{37}$

Augustus II attempted to strengthen the ranks of his supporters through his prerogative to appoint officials. Nevertheless, in Lithuania, he failed to weaken the Muscovite camp. Having received a post, Lithuanian nobles first hurried to the Russian ambassador with the assurances that they would not turn away from Moscow and would disobey the King. When Michał Wiśniowiecki being in disfavour with Moscow was appointed the Lithuanian chancellor, he and his brother Janusz, palatine of Cracow, paid a visit to the Russian ambassador and asked for 'the tsar's amnesty by solemnly swearing allegiance to Russia' ${ }^{38}$ In his attempt to draw the influential Lithuanian Field Hetman to his side, the King granted him the palatinate of Polotsk. Denhofas immediately sent his brother to the Russian ambassador to ensure him that his brother would continue 'serving the tsar' ${ }^{39}$ Polish officials behaved similarly, too, for example, the Polish grand custodian Stefan Potocki, being appointed palatine of Bełz in $1720 .^{40}$

${ }^{37}$ O Zaranke prezhnim ia donosil, chto onoi prisylaet, chtob emu ni chem ne verit' neizvolili, ibo vse donosit ot sebe nepravdu i opisyvaet drugikh za svoi partikuliarnye zloby naprasno, tokmo chrez to sebe khochet vymanit', kak odnomu $v$ vashikh vysokikh interesakh sluzhit',...ne izvolite odnomu nichego davat', ponezhe v nem net nikakogo dela - G. Dolgorukii to Peter I, report no. 3 of 16 (27) Nov. 1720, Warsaw, AVPRI, f. 79, op. 1, 1720, d. 7, fos. 49-50v.

${ }^{38}$ G. Dolgorukii to Peter I, report no. 6 of 6 (17) Febr. 1720, Warsaw, ibid., fos. 94-95.

${ }^{39} \mathrm{G}$. Dolgorukii to Peter I, report no. 11 of 12 (23) March 1720, Warsaw, ibid., fos. $169-170$.

${ }^{40}$ G. Dolgorukii to Peter I, report no. 6 of 6 (17) Febr. 1720, Warsaw, ibid., fos. 94-96v. 
When Augustus II endeavoured to have the Czartoryskis among his officials as more loyal to him and more closely related to Poland, the Russian ambassador wrote to St Petersburg that they would feel lonely in Lithuania and would not be able to help the king. ${ }^{41}$

However, the Polish-Lithuanian nobles would not have been real szlachta if they had not indulged in effrontery towards Russia even in an atmosphere of total subservience. There were antiRussian excesses in Warsaw and threats to the Russian resident after the royal election of $1697,{ }^{42}$ occasional assertions of Polish nobles to recapture, if necessary by force, the right-bank Ukraine or at least the disputed territory at the River Dnieper, ${ }^{43}$ or the declaration of the Lithuanian vice-chancellor, Stanislovas Antonijus Ščiuka (Szczuka), at the Biržai congress in 1701 that the Commonwealth's entrance in the war against Sweden should be compensated by the return of Smolensk and Kiev, ${ }^{44}$ or occasional humiliation of Russian diplomats, as it was done by the King's favourite the contemporary palatine of Marienburg Jan Przebędowski in 1698. ${ }^{45}$ All that could be treated as a sort of political pressure, though not supported by any real force. In the third and fourth decades of the eighteenth century so-called affronts actually were politically insignificant and rarely were they politically motivated. It was in this sense that I used the term 'caricatured megalomania', which, by the way, was only one step away from servilism. Such was the setting in 1720 when the Commonwealth's official delegation presented an odd request in St Petersburg - to return the jewels of Maria Mniszek, wife of the early-seventeenth-century pretender the False Dmitry, to the Polish marshal Józef Mniszek. ${ }^{46}$ It should be remembered that these were

${ }^{41}$ No oni zelo odinoki $i$ khotia budut storony korolevskoi, odnakozh ni pomoch 'ni povredit' ne mogut - G. Dolgorukii to Peter I, report no. 11 of 12 (23) March 1720, Warsaw, ibid., fos. 169-170.

${ }^{42} \mathrm{G}$. Sliesoriūnas, 'Lietuvos Didžiosios Kunigaikštystès prorusiškos grupuotès formavimosi pradžia (1697 metais)', Lituanistica, (1996), 1(25), p. 29; an extract from A. Nikitin's report, AVPRI, f. 79, op. 1, 1696-1699, d. 7, fos. 17-18.

${ }^{43}$ V. D. Koroliuk, 'Rech' Pospolitaia i podgotovka Severnoi voiny', Uchenye zapiski instituta slavianovedeniia AN SSSR, vol. iv, 1951, pp. 228-236.

${ }^{44}$ Idem, 'Svidanie v Birzhakh i pervye peregovory o russko-pol'skom soiuze', Voprosy istorii, no. 4, 1948, p. 53.

${ }^{45}$ Russian resident A. Nikitin to tsar Peter I [Posolskii prikaz (Foreign Department)], report of 18 (29) May 1698, Warsaw, RGADA, f. 79, op. 1, 1698, fos. 200-201.

${ }_{46}$ Posol zhe polskoi predlagal $v$ konferentsiiakh ministrom nashim i o tom ...podal $i$ na pisme o pretenziiakh marshalka velikogo koronnogo Mnishka predkov ego uchinnenykh ot vora i samozvantsa rostrigi - Peter I (Russian College of Foreign Affairs, St Petersburg) to G. Dolgorukii, instruction no. 30 of 24 July (4 Aug.) 1720, ibid., d. 5, fos. 54-67. 
very significant talks on issues of great importance for the Commonwealth: the conditions concerning the end of the Swedish war and of the peace treaty, the fate of Riga and Livonia, that is the territories once promised to the Commonwealth, the release of prisoners former citizens of the Commonwealth, who had fought on Leszczyński's side, and the return of property, for example cannons taken by Russia during the war. It was not the most opportune moment to require the jewels of an impostor's wife lost in Russia more than a hundred years earlier. Having found their tongue, the Russian negotiators declared that they could not even report about such a request to Peter I. It was understood as an insult to the Romanov dynasty and could be considered as a casus belli. ${ }^{47}$ However, the most interesting thing is the sequel to this story. The Russian ambassador in Warsaw was instructed, if he considered that Russia could have any benefit from this matter, he could give Mniszek some gift; but it had to be presented not as a compensation for Maria Mniszek's jewels. ${ }^{48}$ That shows that even Peter I could keep his temper if it was in the interests of strengthening Russia's political influence among the Commonwealth's nobility. The ambassador approved that decision indicating that the marshal of Poland was the first minister and that it was useful to have him on one's side. Mniszek was a person of Augustus II's entourage, consequently he was in opposition to the pro-Russian grouping. Mniszek's name is connected with one more episode that could be considered rather typical. During the sejm of 1720 an officer hired by the Russian ambassador arrested a Ukrainian Cossack on a Warsaw street for his participation in a riot against the tsar. ${ }^{49}$ The Cossack was imprisoned in the ambassador's residence, ${ }^{50}$ and later was taken

47 ...ministry nashi protiv togo emu poslu obiavili, chto o sei merzkoi pretenzii $i$ upominat' im nepristoino, ibo vsemu svetu izvestno, kto onoi vor rostriga byl $i$ kakoe on pri vspomozhenii polskom Rossii razorenie prikliuchil, $i$ mogli b my prichinu imet' naipache za to mstit' tem, kto tomu plutu v ego zlykh bezchelovechnykh predpriiatiiakh sposobstvoval - Peter I (Russian College of Foreign Affairs, St Petersburg) to G. Dolgorukii, instruction no. 30 of 24 July (4 Aug.) 1720, ibid.

${ }^{48}$ I ezheli on Mnishek vam $k$ interesam nashim potreben, to mozhete ego chem nibut' iz nashei kazny podarit', odnako pri tom obiavit', chto to chinish ty po ukazu nashemu ne dlia toi pretenzii, kotoruiu my za nepravilnu priznavaem, no dlia ego zaslug - ibid.

${ }^{49}$ G. Dolgorukii to Peter I, report no. 14 of 3 (14) Dec. 1720, Warsaw, ibid., d. 7 a, fos. $183-188$.

50 ...onoi v moei kvartire sidit okovan - ibid. 
secretly to Russia. ${ }^{51}$ Mniszek, as the marshal of Poland responsible for the order at King's residence and at the place of the sejm sessions, handed in an extremely harsh note to the Russian ambassador in which he threatened to deprive the diplomat of his immunity and requested to give those who participated in the Cossack's arrest in charge of the court of the Polish marshal. ${ }^{52}$ The ambassador informed St Petersburg that he feared very much that the Poles could occupy his residence by force. ${ }^{53}$ When it was learnt that the ambassador's prisoner was taken to Russia the judge of the marshal court Konstantin Józef Mokronowski sent one more protest to Russia's diplomats. ${ }^{54}$ However, shortly the Russian diplomats in Warsaw informed St Petersburg that the grand marshal of Poland presented privately his excuses for his roughness. He had to behave in that way under pressure of other Polish ministers and delegates of the sejm! At the same time he asked the ambassador to mediate in the issue of the return of the jewels. ${ }^{55}$ I believe that closer examination would reveal similar silent apologies after 'categorical public protests' not only in the eighteenth century but later as well.

Finally, I would like to accentuate one more aspect in the relations between the Lithuanian nobility and Russia. Although in the period under consideration Russia still bribed, made payoffs and ingratiated itself in various ways with Lithuanian and Polish noblemen, where it was possible it behaved in a simpler way and economized its resources. That is obvious in the cases when Russia's dissatisfaction was caused by less influential povet officials or boyars from border palatines. Thus, in 1722 in Dünaburg an oberburggraf of the Duchy of Courland by the name Kościuszko (afterwards the name became famous) was elected a delegate to the sejm. When he

51 Secretary of the Russian embassy Petr Golembowski to ambassador G. Dolgorukii, report of 18 (29) Febr. 1721, Warsaw, ibid., 1721, d. 6, fos. 32-33v.

${ }^{52}$ Mniszek's protest to the Russian envoy G. Dolgorukii, [Jan. - Febr.] 1720, d. 7, fos. 74-76.

53 A pache opasaius', chtob nerespektuia moego posolskogo kharakteru nasilno priekhav ne otniali - G. Dolgorukii to Peter I, report no. 42 of 3 (14) Dec. 1720, Warsaw, ibid., d. 7a, fos. 183-188.

${ }^{54}$ Golembowski to ambassador G. Dolgorukii, report no. 9 of 4 (15) March 1721, Warsaw, ibid., 1721, d. 6, fos. 42-45v.

${ }^{55}$ Gospodin marshalok velikoi polskoi pripominaet vysokoi milosti i predstatelstvu vashei svetlosti interes svoi...I ezheli vashei svetlosti dogrubil v dele Gertsika kazaka, to prosit $v$ tom proshchenii, ponezhe...ne mog inako postupit'...kogda mnogie svoi brat'ia ministry $k$ tomu de menia prinudili - Golembowski to ambassador G. Dolgorukii, report no. 14 of 15 (26) Apr. 1721, Warsaw, ibid., fos. 57-59. 
quarrelled with Russia, its ambassador got the following instruction from the tsar (recently styled 'emperor'): A ezheli usmotrish ty kakie ot nego $k$ interesam nashim protivnosti, to nadlezhit tebe emu pristoinym obrazom ob 'iavit' na edine (my emphasis), chtob on ot takikh protivnykh postupkov uderzhalsia, ibo $v$ protivnom sluchae my vsegda sposoby naidem ego po nadlezhatelstvu $k$ rezonu privesti. ${ }^{56}$ In other words it meant that Russia was going to arrest any delegate to the Commonwealth sejm for demonstrating any illfeeling towards it as soon as he returned to his estates in the palatinate of Livonia or in Courland. Four decades would pass before Russia would be able to take the liberty of behaving in that way not only with the gentry of the border regions but also with the senators and ministers in Warsaw. And the Lithuanian noblemen, active at the end of Augustus II's rule, more than anybody else contributed to the strengthening of this tendency instead of curbing it when that was still feasible.

However, the majority of Lithuanian noblemen were guided by the maxim, current in Poland and Lithuania in the eighteenth century, which stated that a gentleman, selling his vote for money or any other award in the dietine, tribunal or sejm was demonstrating that he was a free person because neither a slave nor a serf was paid, instead they were simply given orders. ${ }^{57}$ After Peter I had bought the votes of the Lithuanian nobility, Catherine II could lord it over their children and grandchildren.

Translation: Alfonsas Laučka

\section{Author Details}

Dr Gintautas Sliesoriūnas is a member of the Department of the History of the Grand Duchy of Lithuania, the Lithuanian Institute of History. He researches the political and social situation in Lithuania in the 17th and 18th centuries.

Address: Lithuanian Institute of History, Kražių 5, 01108 Vilnius, Lithuania Email: slgintas@centras.lt

${ }^{56}$ Peter I (Russian College of Foreign Affairs, St Petersburg) to S. Dolgorukii, instruction no. 22 of 19 (30) Oct. 1722, ibid., d. 5, fos. 62-66.

${ }^{57}$ Kurek, U schytku panowania, p. 55. 


\section{LIETUVOS IR LENKIJOS ELITO POŽIŪRIO İ RUSIJĄ KAITA XVII A. PABAIGOJE - XVIII A. PRADŽIOJE}

\section{Santrauka}

\section{GINTAUTAS SLIESORIŪNAS}

Šiame straipsnyje analizuojama, kaip formavosi servilizmo apraiškos LenkijosLietuvos Respublikos didikų santykiuose su Rusija XVIII a. pirmajame trečdalyje. Nors aptariamas visas Augusto II valdymas (1697-1733 m.), tačiau didžiausias dėmesys skiriamas laikotarpiui po $1719 \mathrm{~m}$. Vienos sutarties, kai Augustas II pabandè išsivaduoti nuo Rusijos priklausomybès, o pastaroji ėmė aktyviai formuoti savo šalininkų grupuotę tarp Respublikos didikų ir kompromituoti Augusto II politiką, noredama ateityje išardyti Lenkijos-Lietuvos Respublikos ir Saksonijos asmeninę uniją.

Galime ižvelgti keturis Respublikos elito santykių su Rusija etapus minimu laikotarpiu. Pirmasis - beveik lygių partnerių aljansas (1697-1702 m.). Antrasis etapas kai Respublika tapo Rusijos subsidijuojama sajungininke (1702-1706 m.). Trečiasis etapas - nuo 1706 iki 1719 m., kai Respublika nusirito iki priklausomo nuo Rusijos, ,jaunesniojo partnerio“. Ir ketvirtasis - nuo 1719 m. iki Augusto II valdymo pabaigos 1733 m., kai Rusija èmė aktyviai puoselèti savo „penktają koloną“ Respublikos elito terpèje. Patikimiausiais ir aktyviausiais Rusijos pagalbininkais tuo metu tapo Lietuvos Didžiosios Kunigaikštystės didikų dauguma. Sraipsnyje aptariami Rusijos diplomatijos naudoti metodai-karaliaus politikos diskreditavimas, gandų platinimas, didikų savimeilès skatinimas, saugumo garantijų suteikimas, papirkinèjimas, galiausiai - šantažas ir bauginimai.

Straipsnyje remiamasi Rusijos Imperijos Užsienio politikos archyve surinktais dokumentais. 